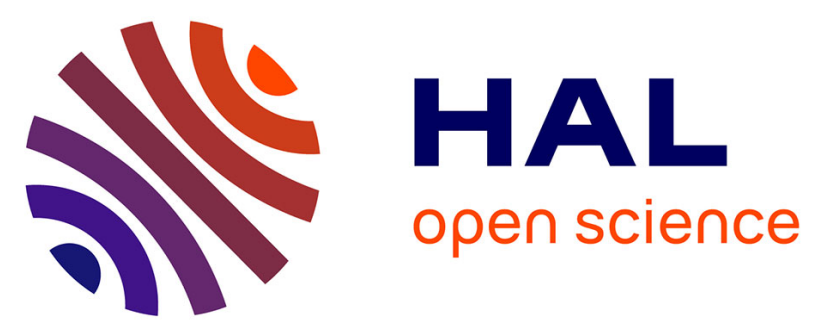

\title{
Curcumin modulates endothelial permeability and monocyte transendothelial migration by affecting endothelial cell dynamics
}

Laurent-Emmanuel Monfoulet, Sylvie Mercier, Dominique Bayle, Nicolas Barber Chamoux, Dragan Milenkovic

\section{To cite this version:}

Laurent-Emmanuel Monfoulet, Sylvie Mercier, Dominique Bayle, Nicolas Barber Chamoux, Dragan Milenkovic. Curcumin modulates endothelial permeability and monocyte transendothelial migration by affecting endothelial cell dynamics. 8. international conference on polyphenols and health, Oct 2017, Québec, Canada. 2017, 8th International Conference on Polyphenols and Health. hal-01607372

\section{HAL Id: hal-01607372 \\ https://hal.science/hal-01607372}

Submitted on 2 Jun 2020

HAL is a multi-disciplinary open access archive for the deposit and dissemination of scientific research documents, whether they are published or not. The documents may come from teaching and research institutions in France or abroad, or from public or private research centers.
L'archive ouverte pluridisciplinaire HAL, est destinée au dépôt et à la diffusion de documents scientifiques de niveau recherche, publiés ou non, émanant des établissements d'enseignement et de recherche français ou étrangers, des laboratoires publics ou privés.

$$
\text { Copyright }
$$




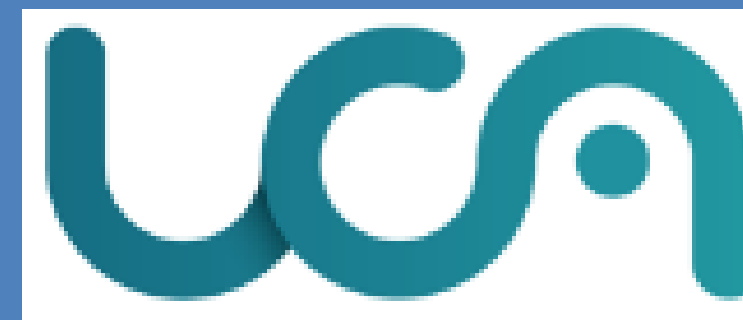

U N I VERSITE Clermont Auvergne
Curcumin modulates vascular endothelial permeability and monocyte transendothelial migration by affecting endothelial cell dynamics

\section{L-E Monfoulet ${ }^{a}$, S Merciera, D Bayle ${ }^{a}$, N Barber-Chamoux ${ }^{a, b}$, C Morand ${ }^{a}$, D Milenkovic ${ }^{a}$}

a Université Clermont Auvergne, INRA, UNH, CRNH Auvergne, F-63000 Clermont-Ferrand, France

${ }^{b}$ CHU Clermont-Ferrand, Service de Cardiologie, F-63000 Clermont-Ferrand, France.

Curcumin is a phenolic compound that exhibits beneficial properties for cardiometabolic health. We previously showed that curcumin reduces the infiltration of immune cells into the vascular wall and prevented atherosclerosis development in mice.

This study aimed to investigate the effect of curcumin on monocyte adhesion and transendothelial migration (TEM) and to decipher the underlying mechanisms of these actions.

\section{Effect of curcumin on monocyte adhesion to endothelial} cells and their transendothelial migration (TEM)
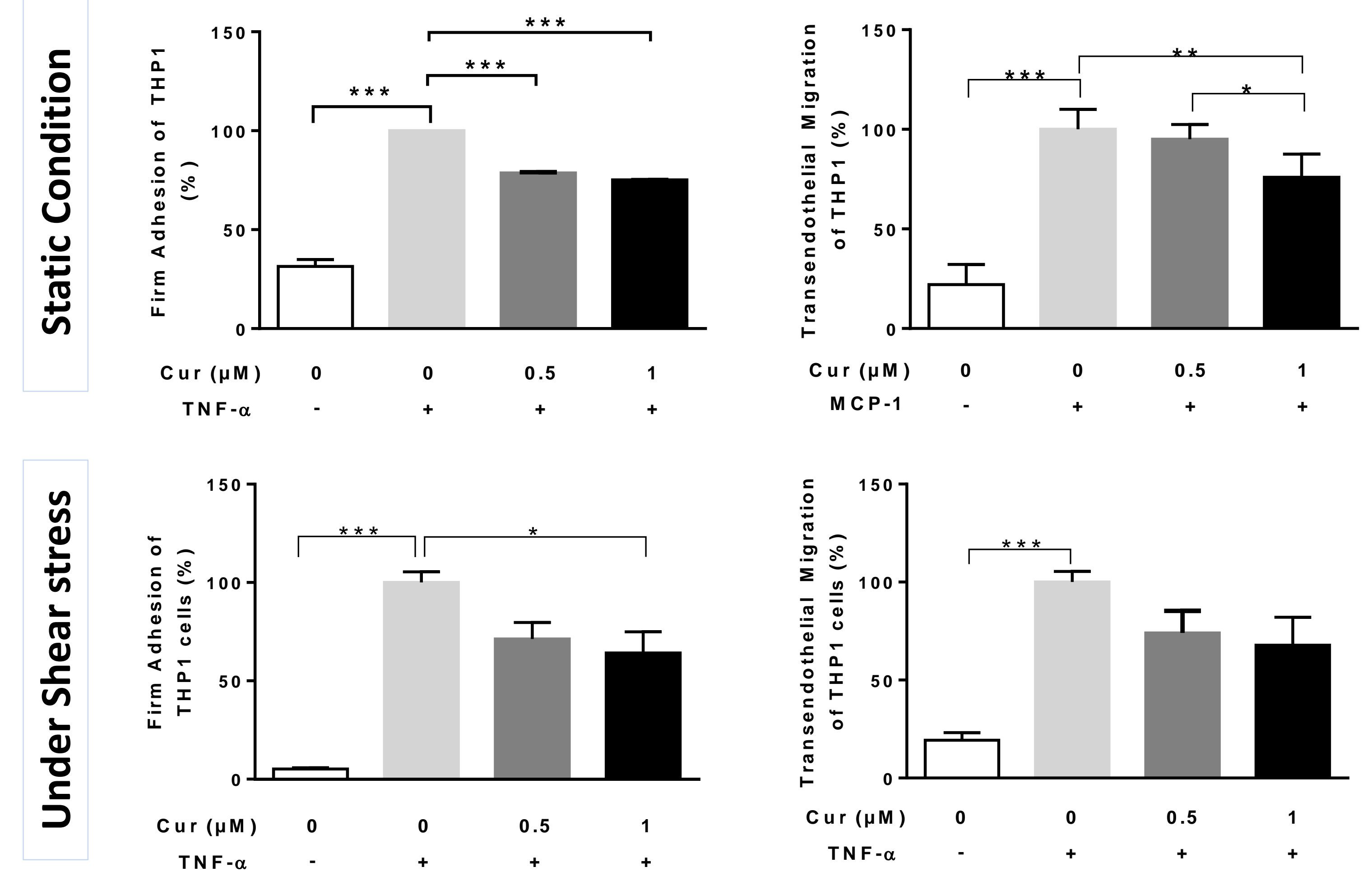

showed that a pre-exposure of HUV

Study Design: Human umbilical vein endothelial cells (HUVECS) were exposed to curcumin (0.5-1 $\mu \mathrm{M})$ for 3 hours prior to their activation by Tumor Necrosis Factor alpha (TNF- $\alpha$ ).

\section{Effect of curcumin on endothelium integrity \\ A}
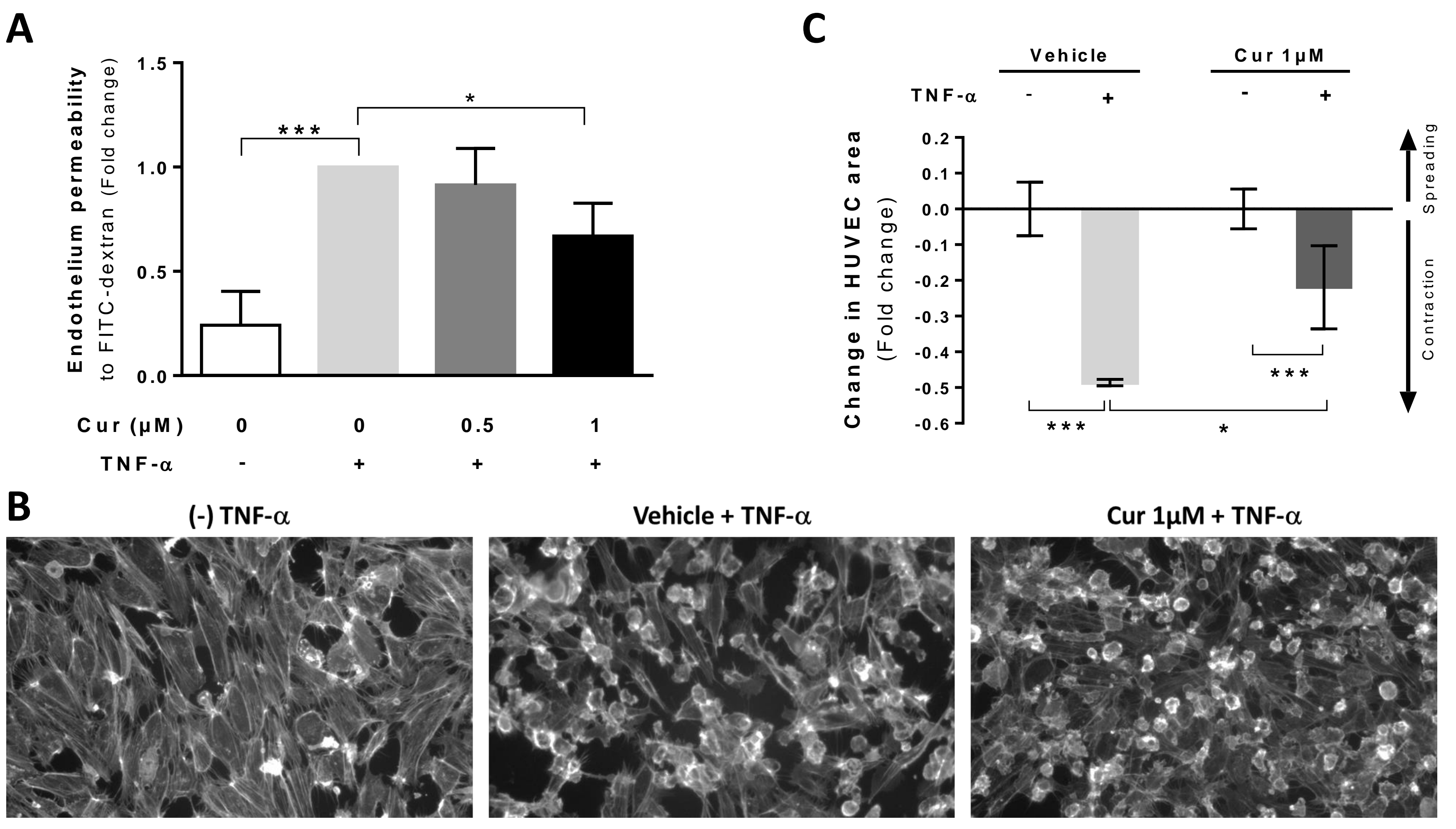

Cell permeability assays, performed using Transwell system, revealed that a preincubation of endothelial cells with $1 \mu \mathrm{M}$ curcumin reduced by $34 \%$ the increase of endothelial permeability to FITC-dextran induced by TNF- $\alpha$ (A). In addition, exposure of endothelial cells to $1 \mu \mathrm{M}$ curcumin reduced by $50 \%$ the TNF- $\alpha$-induced contraction of HUVECs $(B-C)(p<0.05)$.

\section{Impact of curcumin on endothelial adhesion molecules and on NF-KB signaling pathway proteins in HUVECs.}
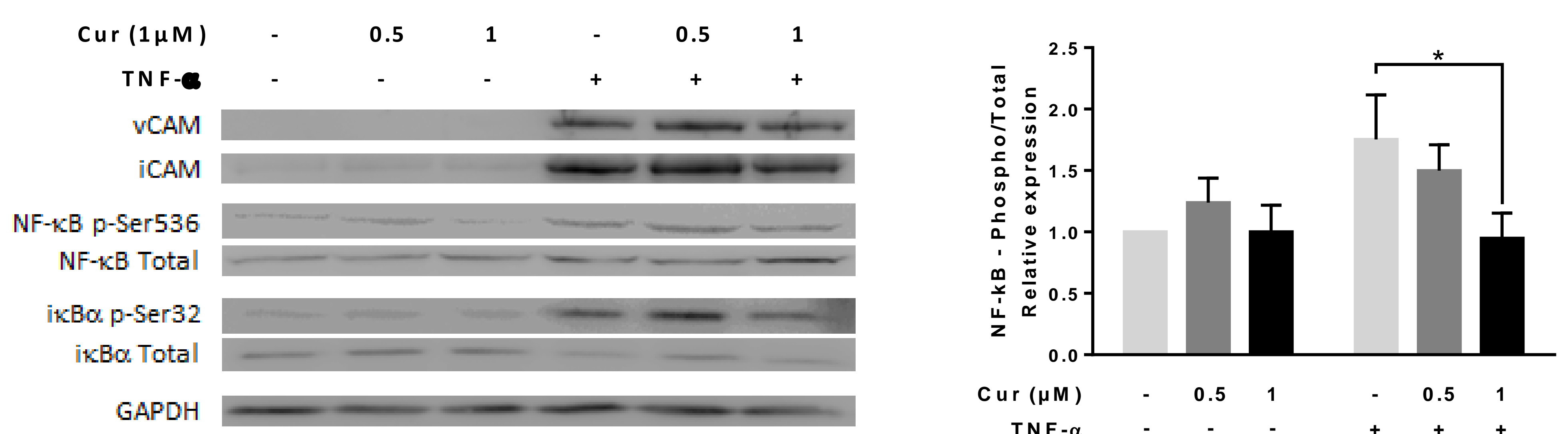

Expression of 93 genes coding proteins involved in TEM quantified by TLDA. Values (mean + /- SEM, $n=4$ ) indicate gene expression fold change measured in $1 \mu \mathrm{M}$ Cur/+TNF- $\alpha$ HUVECs compared to Vehicle/+TNF- $\alpha$ exposed HUVECs.

The exposure of HUVECs to $1 \mu \mathrm{M}$ curcumin prior to TNF-a-activation did not affect the expression of adhesion molecules (VCAM, iCAM) highly induced by TNF- $\alpha$. However, it significantly reduced the level of phosphorylation of NF- $\kappa B$ p 65 without affecting that of $I \kappa B \alpha$.

\section{Conclusion}

Mechanisms of action of curcumin in endothelial cells
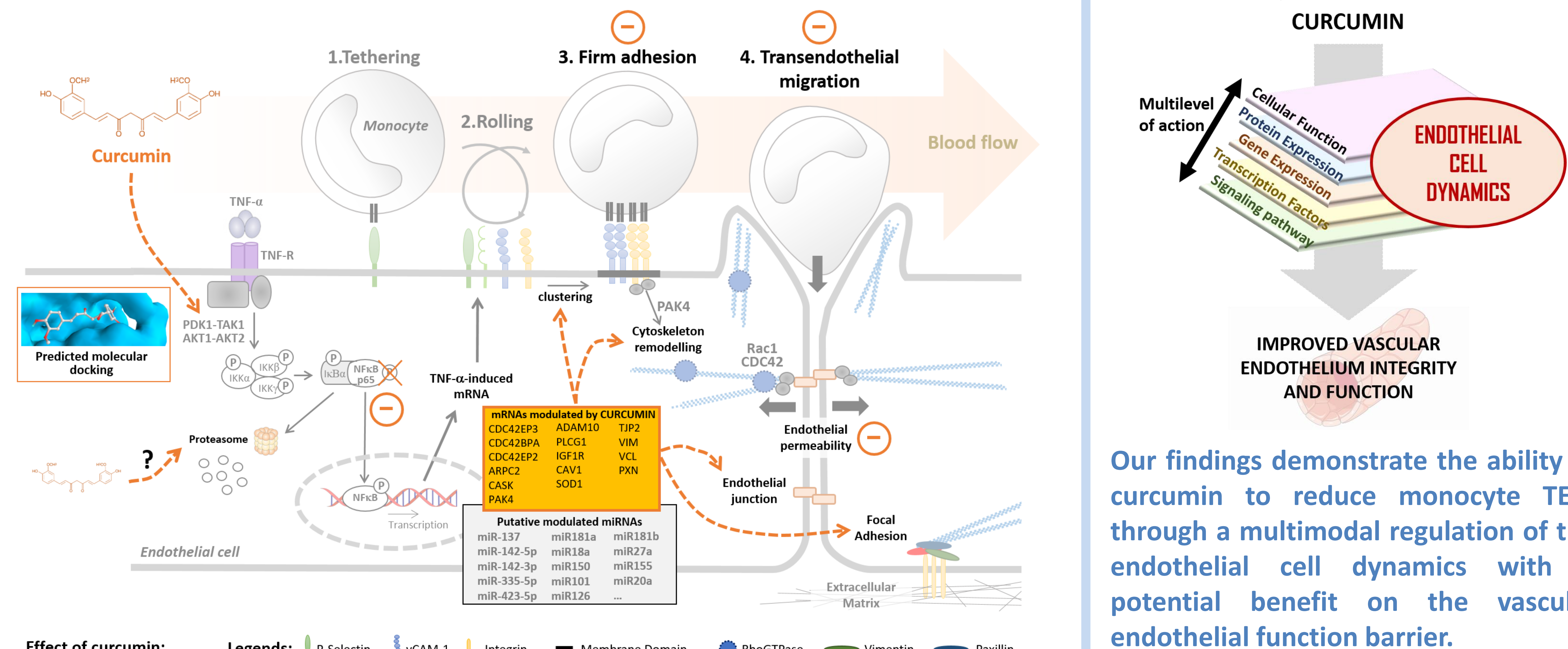

Our findings demonstrate the ability of curcumin to reduce monocyte TEM through a multimodal regulation of the endothelial cell dynamics with a potential benefit on the vascular endothelial function barrier. 